\title{
The Debt of Modern Japanese Law to French Law
}

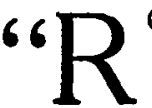

OME," says the great Jhering, "conquered the world three times: first by her armies, second by her religion, third by her law. This third conquest, most pacific of all, is perhaps the most surpassing of all."1 Not the least among the juridical conquests of Roman law is modern Japanese law via the world-influence of French law.

The story of the creation and development of the present law of Japan, through vivifying contact with western civilization, which began barely half a century ago, is nothing short of marvelous. Modern Japan had its beginning in 1868, when the Shogunate was destroyed and the Mikado's authority was restored. At that time the law of Japan was almost entirely customary, full of uncertainty and variability, and thoroughly tinged with Japanese feudal conceptions.

The restoration of the Mikado's authority occurred during the period of French influence in the Far East due to the policy of Napoleon III. Several features of French civilization, such as the re-organization of the Japanese army on the French model, had already been introduced during the last years of the Shogunate; after the Restoration, the influence of France was continued under the Imperial government. ${ }^{2}$

Almost the first task of the Mikado's advisers was the reformation of Japanese law. The Japanese government looked to France to direct this great undertaking. Indeed, Japan could not have looked elsewhere: English law was then not codified (as it is today) and was uncertain; there was no national German law or

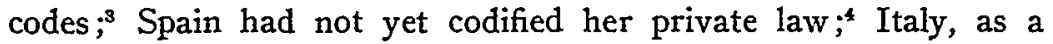

1 Sherman, Roman Law in the Modern World, vol. i, \$11. Future reference will be made to this volume of Sherman's work.

2 Sherman, § 311.

3 The German Civil Code, drafted in 1896, went into effect in 1900: Sherman, § 344 .

4 The Spanish Civil Code was promulgated in 1889: Sherman, 305. 
nation, was a mere infant, and the Italian codification was little known internationally; 5 France alone possessed a well-known system of codified law, easily obtained and comprehended. ${ }^{\mathbf{B}}$

To assist the Japanese government in modernizing the law of Japan, France sent over to Japan three talented jurists: Boissonade, Bousquet, and Benet. "Of these Boissonade was to become the most famous. All three were appointed counsellors to the Minister of Justice. Their duties were very interesting, and opened the way for French law to influence Japanese law. They endeavored to give to the Japanese judges the principles of law on which their decisions should rest; they assisted in the promulgation of isolated law; and they did more than this: in hard cases these Frenchmen, whenever consulted by the Japanese judiciary, would render judgment themselves, and their opinions became at once the decisions of Japanese tribunals. Thus a Japanese jurisprudence grew up under French direction. Naturally, these French jurists in the Japanese service followed, if possible, the principles of French law, and consequently, the Code Napoleon came to exercise great influence in Japan."?

But Japanese law was also influenced by French law through a second channel,-law schools. ${ }^{8}$ In 1872 a school of law was formed at the Ministry of Justice, in which school Boissonade and Bosquet taught French to would-be judges. This was succeeded in 1876 by a "Special School of French Law," which continued at the Ministry of Justice until 1885. Here French law was taught in the French language. In 1877 the Japanese government established another law school, at which French law was studied in the Japanese language. The earliest university law schoolthat of Tokio-antedates the first government law school by two years, being organized in 1870. Boissonade and other Frenchmen taught at the Tokio University Law School. Private non-official law schools also sprang up at.Tokio; in particular, there were five at Tokio, all of which were under the influence of French law and two of which actually taught it. Many standard French

5 The Italian Civil Code was promulgated in 1866: Sherman, § 224.

- The French Civil Code-the Code Napoleon-was promulgated in 1804: Sherman, \& 254.

7 Sherman, \& 311 .

${ }^{8}$ Id., § 311. 
law treatises were brought to Japan and thus stimulated the already large influence of French law in the Mikado's realm. Thousands of Japanese law students were led to take for their inspiration French law, the Roman element of which is admittedly the predominant strain.

Consequently, it is no exaggeration to say that, resulting from the labors of the French jurists in the Imperial Japanese service and from the teaching of French law at the various Japanese law schools, the French Civil Code became the actual basis of Japanese law from the year 1870 to $18900^{\circ}$

Finally, Japanese law was influenced by French law through a third channel,-codification. The movement to codify Japanese law began in 1872, almost immediately after the Restoration of the Mikado's authority. The first Imperial Minister of Justice, Yeto, advanced the project of a Civil Code for Japan, and commenced its preparation with the assistance of the French jurist Bousquet. The preliminary step had already been taken by the Japanese jurist Hitzukuri's translation of the French Civil Code for the use of Japanese judges. In the year 1879 Yeto's project of a Japanese Civil Code, continued by his successor, Count Oghi, was intrusted by the latter to Boissonade. This distinguished French jurist in the Japanese Imperial service worked on the task for ten years being assisted by three Japanese jurists who were to give the native law its proper consideration. But these Japanese assistants as it later appeared, drew more heavily on the French than on their own native customary law. Boissonade's code, when completed, was accepted by the Imperial Council of State, and was promulgated to go into effect in 1893.

Then a reaction against the new Civil Code occurred. Its opponents urged that Boissonade's work was too large a reproduction of the French code $;^{10}$ that it ignored the nearly completed German Civil Code; and that it was not sufficiently conformable to the native Japanese law. Moreover, certain Japanese jurists, with English law proclivities, tried hard to upset entirely the movement

9 Id., § 311, and Japanese authorities therein cited.

10 "In his commentary Boissonade indicated under each article of his draft the corresponding articles of the French and Italian codes:" Sherman, $\$ 312$. The Italian Code, one of the jurisdical offspring of the French, is in some respects the superior code. 
for codification by denying the necessity for any codification whatever, but their efforts failed.

The result of the opposition to Boissonade's code was that in 1892 its promulgation was postponed until 1896, and a commission was appointed to revise it. The membership of this commission included not only jurists acquainted with French law, but also those acquainted with German and English law. The commission worked for three years, and the result of their labors was a wholly different code from that of Boissonade. The new code became the present Japanese Civil Code, which went into effect in 1898. But although Boissonade's code never became the law of Japan, yet in reality between the years 1880-1896 it should not be overlooked that Boissonade's code was applied by the Japanese judges whenever possible; during the decade before 1890 they employed Boissonade's code and the French; and for six years after 1890 they used Boissonade's code exclusively. ${ }^{11}$

The new German Civil Code of 1896 is responsible for the philosophical flavor and the order of arrangement of the present Japanese Civil Code. ${ }^{12}$ Yet, in spite of this Japanese borrowing of legal theory from Germany, the influence of French law has vigorously persisted in modern Japanese law : about one-half of the provisions of the Japanese Civil Code come directly or indirectly from French law. ${ }^{13}$

This striking consequence is the final outcome of the unbroken influence of French law in Japan for the first quarter of a century (1870-1896) after Japan began to strive to become modernized. The following are brief characterizations of the French law influence scattered throughout the present Japanese Civil Code. ${ }^{14}$

Book 1. General provisions (articles 1-174). The Japanese provisions as to capacity, domicil, and prescription are derived from the French Civil Code.

Book 2. Rights in rem (articles 175-398). Many of the

11 Sherman, \& 312 .

12 The native customary law is responsible for the code provisions as to family organization, which is pectiliarly Japanese.

13 Sherman, $\$ 313$. Althotigh Boissonade's code failed to become law, it prepared the way for the present Japanese Civil Code.

14 English translations of the Japanese Civil Code have been made by Lönholm, DeBecker, and others: See Sherman, vol. iii, § 978. 
provisions of the Japanese Civil Code as to possession, ownership, servitudes and mortgages consist of practical rules borrowed from the French Code.

Book 3. Obligations (articles 399-724). This part of the Japanese Civil Code is full of practical provisions evidently inspired by the French Code.

Books 45. Family and succession (articles 725-1146). Although in this part of the Japanese Civil Code are embodied the rules derived from the native Japanese customary law, yet in this part of the Code are also a number of provisions which are borrowed from the French Code.

Modern Japanese law constitutes perhaps the most remarkable illustration of the vast influence wielded by French law on the rest of the world since the Napoleonic codification a little over a century ago. How is this world-influence of the French Civil Code to be explained? The answer is: because the French Civil Code consecrates "the best form of the social state," it has become "the Code of the modern civilized world," as the great historian Thiers so lucidly observes. ${ }^{15}$

Charles P. Sherman, D. C. L.

Yale University. 726.

${ }^{15}$ Histoire, du consulat et de l'Empire, vol. iii, pp. 344-345; vol. iv, p. 